Linguistik Terapan 18 (2) (2021): 166 - 171

Jurnal Linguistik Terapan Pascasarjana

Available online

http://jurnal.unimed.ac.id/2019/index.php/JLT-Unimed

\title{
CULTURE AND INTERLANGUAGE STAGES EFFECT ON EFL STUDENTS' POLITENESS IN REFUSALS
}

\author{
Widya Wulandari \\ Berlin Sibarani \\ Anni Holila Pulungan \\ English Applied Linguistic Program \\ Postgraduate Program-Universitas Negeri Medan
}

Diterima Mei 2021; Disetujui Juni 2021; Dipublikasikan Agustus 2021

\begin{abstract}
The objectives of this study is to investigate the culture and interlanguage stages effect on EFL students' politeness in refusals. This study was a qualitative research. The data were taken from refusal expressions made by EFL Malay and Batak Junior high school students with initial stage (stage 1 interlanguage) and free variation stage (stage 2 interlanguage). The data of this study were collected by using elicitation techniques by using Discourse Completion Task (DCT), pictures and Interview. The number of the subjects involved in this study was taken by using snowball technique and the total number were twelve subjects. The results of this study showed that both culture and interlanguage stages affect the EFL students' politeness in refusals. In Bataknese EFL students, the realization of politeness in refusal tends to be more affected by the culture rather than the interlanguage stages. While in Malay, culture and interlanguage stages have the same effect in the realization of politeness in refusals.
\end{abstract}

Keywords: Culture, Effect, Interlanguage Stages, Politeness, Refusals

How to Cite: Wulandari, Widya (2021).Culture and Interlanguage Stages Effect on EFL Students' Politeness in Refusals. Jurnal Linguistik Terapan Pascasarjana Unimed. 18 (2): $166-171$.

ISSN: $2407-7410$

\section{INTRODUCTION}

Politeness is a way to polish the behavior, minimize conflict, keep cooperative interaction and smoothen the communication. Because of politeness has a great role and impact in communication, the language users or learners do need to be aware and understand about it. Politeness also exist in all kinds of speech act, includes in refusal which is a kind of initial respond of an act which has a great risk in threatening both the speaker and hearer face in communication. Every language community has a system of politeness, but the details 
associated with that system will vary from one culture to other cultures. Watts (2003) states that culture manifests in one's identity, and consequently one's linguistic interpersonal behaviour is regarded driven by one's cultural identity. Cultural effects on politeness are proved by the different strategies used by some Indonesian cultures which have different way in refusal. Bataknese tends to use direct refusal strategy while Malay tends to use indirect strategy.

Furthermore, discussing about English Foreign Language learner, it must also interrelated to interlanguage which is a linguistic stage or new language created by EFL learners. This interlanguage is varied among one students to others. Tarone (2001) explains during the process of L2 learning, the learner create the interlanguage system derived from the learner's internal processing so that the learner's performance is variable and learners interlanguage keep changing until the target language system is fully shaped. Each students has different stages in his interlanguage. This variation and stages seem to have the effect on EFL students' politeness especially in refusals. Based on those two theories about cultural effect on politeness and interlanguage on EFL learning context, the researcher find out the gap between those theories that trigger the researcher to conduct this research in EFL context. Does it culture which make the differences of EFL politeness in refusal? or does it interlanguage stage?

Many previous studies conducted the research related to the culture effects on politeness in refusal such as Satica and Ciftci (2018) who examined refusal strategies of Turkish learners of English and explore their perceptions of social factors that are influential in their strategy use. The findings showed that Turkish learners of English employed a lot more strategies when the initiating act was invitation. Then, Rahayu (2019) investigates the speech act recognition of refusing as made by Indonesian learners of English as a foreign language, native Indonesian, and native English. The results show that Indonesian EFL learners (IELs) tend to use their native culture in refusing. In fact, there is still no researcher which conducts this research in Indonesian EFL learners who have different cultures and interlanguage stages. Based on those explanation, this study aims to investigate the effect of culture and interlanguage stages on EFL students' politeness in refusals.

\section{METHODOLOGY}

This study was a descriptive qualitative design. Bogdan and Biklen (1992) define this design as a kind of research which data are collected in form of words or pictures rather than numbers. In this research, case study was used. 
The data of this study was the politeness in refusal expressions made by EFL Junior High School (JHS) students. The source of the data were the EFL students with different ethnic group (Malay and Batak) and interlanguage stages (stages 1 and 2). The Bataknese JHS students were taken from MTsN Tapanuli Utara while the Malay JHS students were taken from MTs Darul Hikmah Asahan. Those locations were selected because of the consideration of strong cultural atmospheres. The number of the subjects to be involved in this study was taken by using snowball technique and the recurrent or saturation principles. The data of this study were collected by using elicitation techniques by using Discourse Completion Task (DCT), pictures and Interview. DCT is a data elicitation tool in which participants are expected to provide what would be a suitable answer to a given scenario (Roever, 2011). In this research, the written DCT adapted from Wang (2019) were used.

The subjects were asked to write the refusal based on the scenarios written in DCT. They were encouraged to respond spontaneously, and not thinking too much to their responses, then the responses from all the participants were collected as data for analyzing how the subjects form politeness in refusal. Then, they were asked to make the negative sentences based on the pictures to identify their stages. Interview were conducted by the researcher to get more data about the underlying reasons of subjects' refusal expressions. The answer of the interview were noted and recorded by using audio recorder.

\section{FINDINGS AND DISCUSSIONS}

Interlanguge stages of the subjects affect the realization of politeness in refusal is proved by making comparison of the realization among the same culture. The result of such comparison shows that subjects with the same culture but different interlanguge stages shows the difference in the realization of politeness in refusal. Malay subjects with higher interlanguage stages (Free Variation Stage) realized politeness in refusal that more variously than the Malay with lower interlanguage level (Initial stage). The same thing is also true to the Batak subjects. The subject with higher interlanguage level (Free Variation) realized politeness in refusal more variously than the Batak subjects with low level interlanguge. What makes the politeness realization more variously is interlanguuge stages since they have the same culture. So interlanguge stages is considered as the underlying factor affect the politeness realization of refusal. The comparison can be seen in the table below: 
Table 1. The comparison of Politeness in Refusals among Malay and Batak Subjects with Different Interlanguage Stages

\begin{tabular}{|c|c|c|}
\hline \multirow{2}{*}{$\begin{array}{l}\text { Interlanguage } \\
\text { Stages }\end{array}$} & \multicolumn{2}{|c|}{ Different Culture } \\
\hline & Malay & Batak \\
\hline Stage 1 & $\begin{array}{ll}\text { - } & \text { Indirect }: \text { Regret }+ \text { reasons } \\
\text { - } & \text { Direct }: \text { Regret }+ \text { non } \\
\text { performative statement } \\
\text { Direct }: \text { Regret }+ \text { non } \\
\text { performative statement }+ \\
\text { reason } \\
\text { (less indirect way) }\end{array}$ & $\begin{array}{l}\text { - Direct :Regret }+ \text { non } \\
\text { performative statement }+ \\
\text { reason) } \\
\text { - Direct :non-performative } \\
\text { statement + reason }\end{array}$ \\
\hline Stage 2 & $\begin{array}{ll}\text { - } & \text { Indirect ; Regret + reason } \\
\text { - } & \text { Indirect ; regret + reasons } \\
& + \text { future acceptance } \\
\text { - } & \text { Direct ; acceptance as } \\
& \text { refusal + non } \\
\text { performative statement } \\
\text { - } & \begin{array}{l}\text { Direct ; regret + non } \\
\text { performative statement } \\
\text { (more indirect way) }\end{array}\end{array}$ & $\begin{array}{l}\text { Direct (Regret }+ \text { non- } \\
\text { performative statement } \\
\text { +reasons) } \\
\text { - Direct (Regret }+ \text { non- } \\
\text { performative statement }+ \\
\text { future acceptance) }\end{array}$ \\
\hline
\end{tabular}

From the table above, it can be concluded that the realization of EFL politeness in refusal are affected by culture and interlanguage stages. In Batak culture, the realization of politeness in refusal tends to be more influenced by the culture itself rather than by the interlanguage stage. While in Malay, culture and interlanguage stages have the same influence in the realization of politeness in refusals. This is indicated empirical data in which Malay subjects used direct and indirect ways in both stages while Batak subjects keep using direct ways in both stages. The Batak subjects with higher interlanguge level (Free Variation Stage) make no difference in ways of refusing from the Batak Subject with lower interlanguage level (initial stage). They tend to use direct ways no matter their interlanguage is higher. While the Malay subject with lower language level (initial stage) use fewer indirect ways than the Malay subjects with higher interlanguage level (Free Variation Stage).

Based on that finding, this research supports the following previous researches; Amiruddin $\&$ Saleh (2016) state that Malay tends to use indirect strategies to lessen the face-threatening effect of refusal. This findings also agreed with Sianturi (2015) that states that directness is the dominantly used by Bataknese because they do not like talk long-winded. 
In addition, the finding also supported Boangmanalu and Lumbangaol (2016) that explains the politeness principle in Bataknese represented in using the word sorry (santabi, marpanganju, and marpamuati). It means that, although Batakanese used direct strategies do not mean that Bataknese do not use politeness principle in their communication especially in refusals. In relation to the cultural and interlanguage effect on politeness, this study are supported Tabatabei (2019) that states the differences of language proficiency contributes on the length of the refusal produced. In this study, the staged-1 subjects tend to use shorter refusal expressions and less semantic formula. Another researches about politeness and culture in ESL context also support this finding is Brasdefer (2003) found that the lack of second language sociocultural knowledge, make the L2 learners refusals strategies are limited. In this study it is proved by the limited ways used by the subjects and the variation of semantic formulas.

Besides supporting some researches, this finding is also contradict to the Alshakhi (2019) who found that there was no strong correlation between politeness and English language proficiency levels. It is contradictory with the finding that both culture and interlanguage stages affect the EFL politeness in refusals. Based on this new finding, the researcher add the result of Song (2012) where, the previous researcher only proposed four reasons or factors affect politeness in second language learner. Besides power, distance, rank of imposition and culture proposed by Song (2012), interlanguage stages are also the factors affect the politeness in second language / foreign language learners.

\section{REFERENCES}

Al-shahki, A. 2019. The Relationship Between English Language Proficiency and Politeness in Making Requests: A Case Study of ESL Saudi Students. International Journal of English Linguistics; Vol. 9, No. 2

Amirrudin, S and Saleh N.B, .2016.Refusal Strategies in English among Malay ESL Students. Infrastructure University Kuala Lumpur Research Journal Vol. 4 No.1

Boangmanalu, I.A. and G. Lumbangaol, 2016. Penggunaan Kata Maaf dan Terimakasih: Kesantunan Berbahasa Bahasa Batak Toba. Seminar Nasional Prasasti II ; Kajian Pragmatik dalam Berbagai Bidang

Bogdan, R. and S, Biklen . 1992. Qualitative Research for Education. Boston : Allyn and Bacon

Brasdefer,J. 2008. Politeness in Mexico and United States. Philadelpia : John Benjamins Publishing Company 
Brown, P. \& S. C., Levinson. 1987. Politeness: Some Universals in Language Usage. Cambridge: Cambridge University Press.

Iliadi, P. L \& P, Larina. 2017. Refusal Strategies In English And Russian. RUDN Journal of Language Studies, Semiotics and Semantics, Vol. 8 No 3 531-542

Rahayu, N.S. 2019. Refusal Strategy Performed By Indonesian EFL Learner.Indonesian EFL Journal (IEFLJ) Volume 5, Issue 1

Roever, C. 2011. Testing of Second Language Pragmatics: Past and future.Language Testing, 28(4), 463-481.

Sianturi,S. 2015.The Realization of Politeness Strategies Used by The Toba Batak Teenagers in Lintongnihuta. Methoda Vol 5 No 2

Song, S. 2012. Politeness and Culture in Second Language Acquisition.London : Palgrave Milan.

Tabataei,S. 2019. Language Proficiency and Appropriateness of Using Refusal Speech Acts by Iranian EFL Learners. ALR Journal ; 4(1):35-45

Tarone, E. 2001. Interlanguage. In R. Mesthrie (Eds.), Concise encyclopedia of sociolinguistics (pp. 475- 81). Oxford: Elsevier.

Tobing, Panggabean and Sinar. 2016. Effect-for-Cause Inferencing in the Evaluation of Loudness Among Toba Batak People. Sociolinguistic Studies, Vol 10, No 3

Wang, Q. 2019. A Comparative Study of Gender Differences in Refusal Strategies from English Majors. Theory and Practice in Language Studies, Vol. 9, No. 8, pp. 10401048

Watts, R. 2003.Politeness ; Key Topic in Sosiolinguistic. New York : Cambridge University Press. 